\title{
The Development of Local Osirian Forms. An Explanatory Model
}

\author{
Lucía DÍAZ-IGLESIAS LLANOS
}

\begin{abstract}
This contribution aims to propose an explanatory model for the origin and meaning of the local manifestations of Osiris, based on Whitney Davis' ideas on the mechanisms governing the development of ancient Egyptian iconographic representations. Four case studies are presented (Wsjr Hnty-hrty, Wsjr Hm3g, Wsjr jty hry-jb T3-šs, and Wsjr $N-3 r=f$ ), highlighting their essential features and local specificities. Davis' concepts of "core motif", "additive modification", and "expressive magnification" are applied here to explain these manifestations and the development of the different local Osirian forms. Finally, the phenomenon of importation and adaptation of prestigious Osirian figures in various localities is explored using Thebes as a case study.
\end{abstract}

Se propone un modelo para explicar la génesis y el significado de las manifestaciones locales de Osiris partiendo de las ideas de Whitney Davis sobre los mecanismos de desarrollo de las representaciones iconográficas egipcias. Cuatro casos de estudio son presentados (Wsjr Hnty-hty, Wsjr Hm3g, Wsjr jty hry-jb T3-š y Wsjr $N-3 r=f$ ), incidiendo en sus características esenciales y sus especificidades locales. Los conceptos de "motivos centrales", "modificación aditiva" y "magnificación expresiva" de Davis son aplicados para clarificar estas manifestaciones y el desarrollo de las formas osirianas locales. Por último, se analiza el fenómeno de importaciones y adaptaciones de figuras osirianas prestigiosas en diferentes centros del país, a través del caso de Tebas.

Keywords: Osiris, local traditions, Whitney Davis, creative reinterpretation, mytheme, Osiris Khenty-Khety, Osiris Hemag, Osiris the sovereign who dwells in the Land of the Lake, Osiris Naref.

Palabras clave: Osiris, tradiciones locales, Whitney Davis, reinterpretación creativa, mitema, Osiris Khenty-Khety, Osiris Hemag, Osiris el soberano que reside en la Tierra del Lago, Osiris Naref.

\section{1 | Osiris: aspects, functions, mythical cycle, and spread of cult}

Within ancient Egyptian culture, Osiris embodied different but interrelated concepts and expectations ${ }^{1}$, such as human rebirth, le- gitimate kingship, succession of generations in society or regeneration of natural and cosmic cycles, the latter manifested through the various phases undergone by plants, the inundation, or the moon ${ }^{2}$. At a mythological level, this deity played many roles as god-

1 Wegner (1996: 11-35) analyses the nature and origins of Osiris, gathering the different interpretations of these issues in two models (that he dubs "standard" and "Griffiths" - referring to the classical study of the latter of 1980, first released in 1966). Mark Smith is currently preparing a monograph on the relationship between Osiris and the deceased in which he re-examines many aspects of the deity and deals with diachronic changes in his figure (a summary of his main lines of research can be found in Smith, 2014).

2 In relation to the different facets of Osiris, Derchain (1969: 167) states: "Il ne s'agirait plus de devenir lequel du dieu funéraire, du dieu lune, du dieu Nil, du dieu agraire, du dieu soleil est à l'origine, et

\author{
TdE 7 (2016) - Páginas: 23-41 \\ Recepción: 10/10/2016 - Admisión: 20/10/2016 \\ Lucía Díaz-Iglesias Llanos - lucia.diaz-iglesias@cchs.csic.es \\ Centro de Ciencias Humanas y Sociales / Consejo Superior de Investigaciones Científicas / Madrid / España
}

http://doi.org/10.25145/j.TdE.2016.07.02 
king, father, victim of fratricide, or judge of the netherworld. All these aspects turned Osiris into a model or mythical precedent in numerous funerary and socio-political contexts in this world and the Beyond.

The mythological cycle of Osiris was in constant construction and re-actualisation, departing from a basic nucleus known through allusions from the earliest funerary sources (Pyramid Texts ${ }^{3}$ and Coffin Texts) ${ }^{4}$ onwards. This cycle was composed of episodes that were never integrated into a coherent linear narrative in native sources. According to the characteristics of ancient Egyptian mythological notions and their setting down in writing, these episodes were articulated in various textual productions as mythemes or brief allusions lacking a fixed form to several events and central situations in the god's lifes: his legitimate reign while alive, his indiscriminate murder by his brother Seth, his mummification and rebirth thanks to the aid of feminine (Isis and Nephthys) and masculine (Horus and Anubis) divine agents, his posthumous conception of an heir, his triumph over his enemies in a lawcourt, his royal leadership in the beyond, or the transfer of royal power to his son Horus so that he can command the living. All these episodes were inextricably linked to the relationships interwoven by Osiris with other deities, which situated him in several divine constellations together with Isis, Nephthys, Seth, and Horus ${ }^{6}$.

Due to the close relationship of Osiris with individual hopes for the afterlife, on the one hand, and with royal ideology, on the other, the religious beliefs and practices linked to his cult reached a wide projection in the territory. In the course of time and in the process of the expansion of Osiris' cult, both his core attributes (his aspects and functions) and his mythical cycle were enriched through the absorption of local traditions, religious beliefs, and practices. This was, in reality, a long-term phenomenon culminating in the New Kingdom and, especially, during the First Millennium BCE in the crystallisation of particular Osirian forms in different regions and localities.

In recent years, this process of expansion and enrichment and the resulting local manifestations of the god have gained relevance as topic of research within Egyptology. Several scholars have summarised, in a very apt manner, the guidelines of this phenomenon. Thus, Laurent Coulon indicates: "l' «osirianisation» est un phénomène d'échalle natio-

comment les autres dérivent de lui, mais au contraire de rechercher quel peut être le noyau commun, la signification générale d'Osiris pour qu'il puisse correspondre à tant des phénomènes différents". This nucleus lies, according to Derchain, in the role of Osiris as bearer of the hope to escape from the definitive death and in the idea of new beginning. In this same venue, a recent study of Allen (2013) about the etymology of Osiris' name concludes that the theonym served to emphasise the notion of "engendering (male) principle", of a cyclical process continuously bringing new life.

3 References to Osiris in the Pyramid Texts are discussed by Meurer, 2002: 63-70, 114-144; Diego Espinel, 2006: 217-239; Mathieu, 2010.

4 For Osiris in the Coffin Texts, see the references provided by Altenmüller, 1975: 42-52.

5 For the concept of mythemes or mythical notions, see Bickel, 1994: 15, 246-256, 273-274; Goebs, 2002; Díaz-Iglesias Llanos, 2014: 13-22.

6 Assmann (1991: 149-176; 2003: 47-51, 61-64, 80-88, 114-125) analyses these episodes and the constellations in question. 
nale, mais qui se décline dans les provinces d'Égypte en autant de variantes régionales s'enracinant dans le substrat des traditions locales. $[\ldots]$ Osiris $[\ldots]$ voit de fait sa personnalité se démultiplier en une myriade de formes particulières, possédant leur individualité er leur clergé propres"7. Meanwhile, Christine Favard-Meeks and Dimitri Meeks underscore that: "les données de base du mythe osirien sont susceptibles d'être habillées de façon différente selon les lieux et, à partir d'une certaine époque, chaque métropole religieuse en avait élaboré sa propre version, adaptée aux besoins des mythes et des rites locaux"8.

\section{2 | Antecedents and initial hypothesis}

It is striking that, at a historiographic level, most studies in local Osirian forms have focused on the First Millennium BCE, and, with rare exceptions, have been developed in the last three or four decades ${ }^{9}$. The first circumstance is derived from the greater abundance of sources for this later peri- od, given that, during the phase starting at the end of the New Kingdom, the growing importance of the Osirian cult ${ }^{10}$ coincided with the increase in channels of religious expressions ${ }^{11}$. Progressively, the brief allusions to actions and situations of the divine world, characteristic of the Old and Middle Kingdom productions, were enriched with contextual details and new characters. Moreover, the trend in the theological speculation towards the "historisation" of the divine community favoured the addition of details and practically led to the shaping of a biography for Osiris ${ }^{12}$. However, this author considers that the "Osirianisation" is rooted in certain regions in the First Intermediate Period and Middle Kingdom. It should be stressed from the outset that this statement does not imply that the process was completely developed by these early periods, nor that all the different local forms of the god which are attested during the First Millennium BCE, sometimes even within one region, can be traced back to this time span. Nevertheless, it is unde-

7 Coulon, 2010: 6-7. This same author underscores: "la montée en puissance du culte osirien dans l'ensemble de l'Égypte à la Basse Époque ne s'accompagne pas néanmoins d'une uniformisation totale des croyances et pratiques cultuelles et les variantes régionales dans les théologies et liturgies mises en oeuvre dans les sanctuaires restent fortes" (2013: 169).

8 Favard-Meeks and Meeks, 2010: 39.

9 Vernus 1978: 419-425; El-Banna, 1989; Zecchi, 1996; Collombert, 1997: 55-61; Gabolde, in Gabolde, Galliano and Ballet, 2000: 106-115; Herbin, 2003; Razanajao, 2006; Zecchi, 20o6; Coulon, works mentioned in the bibliography and in the site: http://www.hisoma.mom.fr/annuaire/coulon-laurent (last accessed 20/11/2015). Among the early contributions, see Rusch, 1957.

10 See the works of Coulon, 2003 and 2010 and Kucharek, 2006.

11 A break in the cultural decorum led to the development of new forms of recording religious beliefs and practices through different avenues: from stelae to votive objects deposited in chapels, temples, and tombs, going through depictions and texts on tomb and temple walls, graffiti, literary, epistolary, and self-presentation texts as well as sources from the household domain. All these documents attest more explicitly than before to the personal interrelationships between individuals and deities: Baines and Frood, 2008; Luiselli, 2014.

12 The process of "historisation" of the divine world has been described by Luft, 1978. The influence of this process on the figure of Osiris has been dealt with by Smith, 2008 and Díaz-Iglesias Llanos, 2014: 336-338. 
niable that the phenomenon which rose to prominence in the Third Intermediate Period and the Late Period had a long process of gestation. Already in the Coffin Texts and in Osirian hymns of the First Intermediate Period/Middle Kingdom, there was a tendency to connect in a preferential (but not exclusive or excluding) and recurrent manner specific features of Osiris or certain episodes of his mythological cycle with given localities ${ }^{13}$. It is highly significant that this connection was not established at random, but rested on elements characteristic of the given locality or region (be them religious traditions, historical and cultural developments, aspects of the local landscape, economic resources, etc.).

The second aforementioned circumstance, the notable development of studies related to Osiris in the local context during the last thirty or forty years, is related to the greater accessibility to primary sources and to new archaeological findings in important Osirian centres in recent times. From the 1960 onwards, the critical edition and detailed analysis of the main texts concerning Osirian rituals, carved on temple walls or written on papyri (chapels in Dendera, $\mathrm{pPa}$ ris Louvre N. 3176, pSalt825) took place. To this scholarly achievement should be added the recent publication of the Osirian liturgies and the so-called priestly manu- als, in which the main religious features of each province were codified. Moreover, in the last decade, several archaeological projects in areas of cult and burial of the god, noticeably in the Osirian chapels and necropolis of Karnak and in the catacombs at Oxyrhynchus, have produced a wealth of archaeological and textual sources, thus increasing the materials at the disposal of researchers ${ }^{14}$.

The ideas unfolded in this contribution are centred on determining the inflections that the figure of Osiris underwent in the diverse Egyptian regions in which he was venerated and on sketching the main avenues of this process. In this sense, it is interesting to bring forward the questions with which Marco Zecchi opens his study on Osiris in the Fayyum: "Did the transposition of Osiris into the Fayyum provide any significant mutation on the representation of his personality? Was there a way of thinking about this god that was typical of this region?"15 Drawing on these questions, and on the studies of Marco Zecchi and of other scholars that will be analysed in section 3 and have been listed in footnote 9, I suggest the following initial hypothesis to understand the figure of Osiris from a local or regional perspective: the basic attributes of Osiris (his main functions and aspects, as well as the mythical episodes defining his life, see section 1) are attested

13 The identification of Osiris with Khenty-Khety (for whom, see section 3.1) begins during the Middle Kingdom and is based on the features that both share on account of their common connection with water (Vernus, 1978: 417). For the links between Osiris and the $20^{\text {th }}$ Upper Egyptian province and the emphasis on certain aspects of the god based on the Herakleopolitan context of religious beliefs and practices, see Díaz-Iglesias Llanos, 2014: passim.

14 The recent achievements are described by Pantalacci (in Coulon (ed.), 2010, IX-X) and Coulon (2010: 2-6, 9-16), with bibliography corresponding to the different types of sources listed. Publications on regional monographs and Osirian liturgies have multiplied in the last five years: Kucharek, 2010; Leitz, 2014a and 2014b; Backes and Dieleman, 2015.

15 Zecchi, 2006: 117. 
to a greater or lesser extent in the different centres where he is venerated. However, the cultic background of a province/region, especially its religious traditions and tutelary deity, as well as the historical and cultural role that the area played (or attributed to it in the collective memory) $)^{16}$ contributed to shape some aspects and central episodes of the god's mythical cycle. Otherwise said, the cultural traditions and historical development of each region provided a different and subtle angle from which to perceive or give emphasis to one or more of Osiris' facets and episodes integrated in his mythological cycle.

The hypothesis presented here has built upon specific research conducted by Pascal Vernus on Athribis (1978) and Marco Zecchi on the figures of Osiris Hemag and Osiris the sovereign in the Fayyum (1996, 2006). Both underscore the weight of the tutelary gods of these regions in the form of perceiving or conceptualising the figure of Osiris within these areas. It also draws largely on my study on Osiris Naref (2017), the manifestation of this deity characteristic of the Herakleopolitan area, which grew out of the mythological traditions of this region. These four case studies, developed in the ensuing section, serve to illustrate how certain Osirian mythological episodes were reshaped or adapted to the local context and how certain features of the god were emphasised depending on this same local context.

\section{3 | Four case studies}

The first two examples to be presented in this section illustrate the historical, religious, and local mechanisms that are behind the process of local re-working of a central Osirian mytheme, the god's rebirth: Osiris Khenty-Khety (3.1) and Osiris Hemag (3.2). The following two cases exemplify how the emphasis of the divine figure that emerges from this re-working could lie on some essential aspects of the deity, providing him with a special nuance: Osiris the sovereign who dwells in the Land of the Lake (3.3) and Osiris Naref (3.4).

\section{1 | Osiris Khenty-Khety}

In the region of Athribis (10 ${ }^{\text {th }}$ Lower Egyptian nome), the local deity was a crocodile called Hnty-hty. He was syncretised with Horus from the Middle Kingdom onwards, as part of a political and religious move promoted by the royal court to bring the saurian divinities closer to the falcon god. The result, represented in the form of Horus-Khenty-Khety, had an outstanding solar character ${ }^{17}$. This solar aspect led to the reshaping of Osiris' resurrection in the area according to a "solar pattern", by means of which the critical phase of rebirth was equated with the daily rising of the sun. In this way, Wsjr Hnty-hity - attested from the

16 Many centres of religious and/or political relevance ended up representing concepts or symbols: thus, Heliopolis was regarded as the "quintessence de sainteté et de prestige spirituel" and a desirable place of provisions and participation in the divine community (Bickel, 1994: 287-291). Meanwhile, Hermopolis was taken as a cradle of knowledge and as an important centre in the production and retrieval of religious and literary texts (Stadler, 2009: 84-94). Herakleopolis Magna was related to purification and to Osiris' assumption of royalty (Díaz-Iglesias Llanos, 2014: passim).

17 For the character of Khenty-Khety, his assimilation to Horus, and his progressive solarisation, see Vernus, 1978: $372-406$. 
New Kingdom onwards and who became the main funerary deity in the region- was qualified in the Twenty-sixth Dynasty as "he who dwells in the sky" (hr(y)-jb pt) after overcoming death. The rebirth process, in so far as he was conceived as a morning god, could be located within the space called $h w t$ ' $3 t$ from the Saite Period onwards. This word designated in origin a solar Heliopolitan sanctuary, which was later transferred to the temple of Osiris in Athribis and served to highlight the solar aspect of Osirian rebirth in this area ${ }^{18}$.

\section{2 | Osiris Hemag}

Osiris Hemag is a deity attested from the Third Intermediate Period onwards, whose cult spread through several localities of the Delta and Upper Egypt from the Saite Period onwards ${ }^{19}$. This example reinforces the idea that a common topic, in this case Osiris' resurrection, could adopt different forms depending on the aspects that were emphasised. It is important to underscore that these aspects were not chosen at random, but were, more precisely, rooted on the traditions of a locality or region. How do these ideas apply in practice to the example of Osiris Hemag? The specificity of this Osirian manifestation lies in the fact that his rebirth was prompted by the container called Hemag, made of gold and precious stones. The divine and incorruptible nature of these materials acted as a stimulus to bring the god back to life. Even though the origin of this Osirian form is not entirely clear, Marco Zecchi points to the probable influence of the religious traditions of the Memphite area, created around its main deities, Sokar and Ptah. These gods, closely connected with metallurgy, craftsmanship, and demiurgic processes ${ }^{20}$, would have thus played an important role in the conception of Osiris Hemag. When comparing the cases of Osiris Khenty-Khety and of Osiris Hemag, it is clear that both share the cycle of death and rebirth, so intimately related to the figure of Osiris. However, they differ in the specific forms in which his resurrection took place and which, for their part, are (re)shaped according to the distinctive substratum of ideas of each region.

\section{3 Osiris the sovereign who dwells in the Land of the Lake}

Osiris the sovereign who dwells in the Land of the Lake (Wsjr jty hry-jb T3-š) is a form that developed in the $12^{\text {th }}$ Dynasty in the Fayyum (an area called the "Land of the Lake" by the ancient Egyptians) in close con-

18 For Osiris-Khenty-Khety, see Vernus, 1978: 419-425, 437 and LGG II, 559. For the Heliopolitan temple hwt ${ }^{\text {} 3 t}$, see El-Banna, 1989: 108, n. 51, Gabolde, 1998: 145-146.

19 Zecchi (1996) has dedicated a monograph to this deity. See also LGG II, 555-556.

20 Sandman Holmberg, 1946: 31-63 has discussed the aspect of Ptah as creator and craftsman. The association of Sokar with metallurgy has been dealt with by Graindorge-Héreil, 1994: 10-14; Borrego Gallardo, 2010: $374,379-396$. The resurrection of Osiris Hemag can also be considered of a solar type, insofar as he achieves rebirth as a young and living god, just as the rising sun does (Zecchi, 1996: 105). Given that Sokar was understood as the expression of solar rebirth of Osiris (see $L \ddot{A}$ V, 1061, s.v. Sokar; Vernus, 1978: 424-425; Graindorge-Héreil, 1994: 14-17), the influence of the Sokar-related traditions in the birth of the figure of Osiris Hemag is also visible in this field. 
nection with the local crocodile god Sobek. The Middle Kingdom royal policy in this region, especially the measures adopted by Amenemhat III, promoted the identification of Sobek with Horus, the latter being a god with a prominent aspect as royal heir ${ }^{21}$. As a consequence of this identification, the mythical episodes centered on the assumption of royalty of the syncretic form Sobek-Horus of Shedet were strengthened. In all probability, this process also had repercussions in the father of Sobek-Horus, Osiris, leading to a redefinition of his nature and of the relationships that linked father and son. Under the form of Osiris the sovereign who dwells in the Land of the Lake, the aspect emphasised was that of guarantor of the continuity of royal power, jty being a title with an important royal load. His task in the region consisted, fundamentally, in legitimising the transmission of the royal office to his son ${ }^{22}$. In turn, Sobek was in charge of fulfilling a filial role of a funerary nature: he would reassemble the body limbs of his father, spread in the area of the Fayyum, and would execute the necessary rites over his corpse ${ }^{23}$.

Over time, this form of Osiris as sovereign (Wsjr jty) develops in the Fayyum area next to the aspect of the god as ruler of the other world (Wsjr hnty jmntt), qualified with his most traditional epithets. The latter is usually mentioned in funerary contexts and is related to the idea that the Land of the Lake was conceived as a place (or one of the places) where Osiris was buried.

\section{4 | Osiris Naref}

The Osirian manifestation peculiar to the Herakelopolitan region, with its capital in $N n-n s w$, was conceived under the name of Osiris Naref or Osiris (of/in) Naref. The mythical episodes occurring in this geographic area and the background of religious beliefs of the zone -especially the character of its tutelary deity, the ram-god Heryshef- contributed to shape this new divine figure ${ }^{24}$. The mythological notions framed in Naref, some of which were already attested in the Coffin Texts and endured until the latest religious and funerary productions (Documents for Breathing and Osirian liturgies), revolve around the burial of the god's body or relics, his vindication before a tribunal, and his assumption or exercise of royal power. All these episodes are interwoven in the regional Osirian mythical cycle, which swung around these same topics but had the capital or the whole region as stages. The third of these episodes, the assumption of royalty, had a notable connection with the prominent royal aspect developed by the ram-god Heryshef. Although the scarcity of

21 The process of syncretism of Sobek with Horus and the progressive increase of the royal aspect of the former, as well as his role in the legitimisation of the royal power have been described by Zecchi, 2010: $3,23-88,102$. For the policy regarding cultic activities and the construction of temples by Amenemhat III in the area, see also Hirsch, 2004: 119-131, 345-368 (Dok. 288-325).

22 For this Osirian form, see: Zecchi, 2001: 65-72, 2006; Widmer, 2010.

23 Zecchi, 2010: 100-101.

24 Coulon and Masson, 2010; Díaz-Iglesias Llanos, 2012, 2014: passim, and 2017 (monograph devoted to Osiris Naref); LGG II, 548. The main episodes of the Osirian mythical cycle which are underscored in the Herakleopolitan region are also dealt with in Díaz-Iglesias Llanos, 2015. 
sources prevents us from determining all the details in the process, it is clear that the rise in prominence of Herakleopolis Magna as the cradle of the Ninth/Tenth Dynasty was accompanied by the promotion of Heryshef as god-king. A distinct trace of this phenomenon is the fact that the epithets of "king of the two lands" (nsw t3wy) and "ruler of the two banks" ( $h k 3 j d b w y)$ were systematically used as markers of his (royal) nature from the New Kingdom onwards.

The combined analysis of the aforementioned mythemes with a study of the etymology of the toponym $N 3 r f$-whose semantic root is formed by the verb $3 r$, "destitute" or "evict" - resulted in the proposal that Naref could be understood from the double perspective of a space and a quality of the god. The figure of Osiris Naref stressed the aspect embodied by Osiris in the Herakleopolitan region, that of a god who cannot be evicted from the position that he has reached in the area because this position is legitimate, dynastic, and inaccessible to his enemies.

\section{4 | Explanatory model of the development of local Osirian forms}

\section{1 | Iconographic foundations}

The studies conducted by Whitney Davies in ancient Egyptian iconography offer, to my understanding, milestones in relation to terminology and functional mechanisms of the process to develop the initial hypothesis concerning the phenomenon of "Osirianisa- tion" (vid. section 2). I will first introduce the grounds of the Egyptian iconographic development according to this author. In the ensuing subsection, I suggest using some of his ideas to propose a general frame of reference or a model that allows the exploration and understanding of the initial formation and characterisation of the local Osirian forms.

Whitney Davis published one of his main works in 1989, which grew out of his doctoral dissertation, centred on what he designated as The Canonical Tradition in Ancient Egyptian Art. In his third chapter, entitled The Order of Iconography, he argues that within Egyptian representations there existed a central nucleus or a series of main motifs (which he termed "core motifs"), which are equivalent to those elements that appear in every context of use and in a highly invariant manner ${ }^{25}$. This idea of core motifs can be related to the core attributes of Osiris, which define the god and were discussed in section 1. Returning to Davis, he points out that, although some representations are similar, Egyptian art is characterised by flexibility. He then goes on to introduce a group of mechanisms through which variability is introduced in depictions while the central nucleus or core endures. Of all the mechanisms defined by the author, I will only retain here those two which can have a direct bearing on the study of Osiris in the local context.

The first of these receives the name of $a d d i$ tive modification (after Davis' terminology). It consists of the use or inclusion of particular details modifying the core, and the case is illustrated by Davis with the motif of victory, whose nucleus is formed by the king smiting

25 Davis, 1989: 64. 
his enemies. The central motif can be complemented by details which can be turned into standard elements of the core. Such is the case of the presence of attendants or certain aspects of the king's panoply. In some cases, these singularities can even introduce slight modifications in the core motif. For instance, if the topographical specification is added to the scene, indicating that the king's sway over his foes takes place in the desert, the attitude of the royal figure can be subjected to minor changes. Thus, his body posture would be modified from a static to a more dynamic pose, and this change can end up being a convention in later representations ${ }^{26}$.

The second mechanism allowing the introduction of variation within Egyptian representations is dubbed expressive magnification or differentiation by Davis. It consists of the use of standard elements in a novel and distinctive way, with a view to achieving a personalised or individualised depiction. Davis uses the example of the hunting iconography, which he considers to be composed of four standard elements: the fleeing preys, a prey that has been captured, the hunter, and the desert landscape. According to this second mechanism, one of these four components can be selected and turned into the centre of individual variation. For example, the single hound dog pouncing on the neck of his prey in scenes of the royal funerary complex of Sahure can appear as a pack of dogs pushing around their victim in the decoration of the mastaba of Mereruka ${ }^{27}$.

It is important to note that the two aforementioned mechanisms, together with others not mentioned in this paper, serve to introduce flexibility within the system of ancient Egyptian artistic representation. Additionally, Davis does not lose sight of the important role played by the context of an image and other factors integrated in a complex system of visual or textual communication -artists/ patrons, audience, media, elements surrounding the core motif- when it comes to evaluating the content and meaning of this image and to explaining its variations ${ }^{28}$.

\section{2 | Application of W. Davis' ideas to the process of "Osirianisation"}

How can we correlate these ideas developed in the field of iconographic production with the process of "Osirianisation" that this paper aims to clarify? (figure 1). Concerning the four Osirian forms that have been discussed in section 3 , I deem that their development and the variation among them follow a similar pattern to the changes described by Davis in the domain of visual representations. In this light, the additive modification takes place when the topographic specification comes into play, manifesting itself in the introduction of details that (re) shape the god's figure or his mythical cycle

26 This mechanism is defined and illustrated with examples of different periods in Davis, 1989: 64-73.

27 Davis, 1989: 73-76 and figs. 4.6.a and 4.9.a. for the scenes of Sahure and Mereruka.

28 Davis, 1989: 72-73, 92-93. Despite not being explicitly mentioned by this author, the purpose or function for which a work was created could influence the emphasis given to particular elements. Smith (2010) insists in this direction in his analysis on the different traditions concerning the reign of Seth. He emphasises that the core of mythological material (or genotext) could be re-elaborated - displaying different aspects of Seth- according to the specific context and function of a given composition (or phenotext). 
according to the spatial scenery, i.e. the region where he is venerated. Meanwhile, with expressive magnification one aspect of Osiris or of his mythical cycle comes to the fore, meaning that this particular aspect gains prominence in the new Osirian form.

As previously mentioned, Davis also points out that these mechanisms to introduce variations in artistic representation are flexible and creative ways of regulating iconographic diversification without transforming the overall meaning. As a result, the central core is concurrently preserved and expanded ${ }^{29}$. In the case of Osiris and following this principle, these modifications and the new added elements did not transform the overall role and core attributes of the god. It is highly significant that Osiris Hemag, the Osirian form whose resurrection was prompted by the container of gold and precious stones (see section 3.2), was also perceived as a king and as a link in the dynastic change through which royal legitimacy is transmitted. Thus, he receives epithets focusing on his royal character: "the eldest son, firstborn of Geb" ( 33 smsw, tp(y) nGb), "king of kings" (nsw n nsww, bjty $n$ bjtyw), or "the one who commands gods and humans" (wd $-m d w$ $n$ ntrw rmtw $)^{30}$. Moreover, his iconography also underscores his sexual power as a begetter of an heir after death ${ }^{11}$. As regards Osiris $j$ ty in the Land of the Lake, this manifestation does not escape from the final fate of Osiris. The Fayyum was conceived as a place of burial of the $\operatorname{god}^{32}$, although this purely funerary aspect was concentrated on a different Osirian form of the area33. Finally, Osiris Naref also keeps the aspect of Osiris linked to death. For this reason, in funerary texts and in Ptolemaic temple inscriptions we find allusions to the concealment and protection of his tomb or his corpse in Naref, or as Osiris Naref.

This model attempting to explain the multiplication of local manifestations of the god considers that the root of the process lies in the reworking or reinterpretation of core attributes of Osiris and well established traditions concerning this deity, which had a wide scope of circulation within the territory. The four case studies presented in section 3 illustrate how his rebirth or his assumption of royal power were central elements of this divine figure upon which the new Osirian versions were conceived in different regions.

29 "In general, in canonical iconography [...] nothing was lost. Core motifs and elements were continually replicated, subdivided, differentiated, and reshuffled, simultaneously conserved and expanded [...] transformational principles like the additive modification of a core element are almost infinitely productive" (Davis, 1989: 92).

30 Zecchi, 1996: 81-82.

31 Zecchi, 1996: 103.

32 In a Ramesside hymn quoted by Zecchi (2001: 71), with a focus on the association of Osiris' corpse resting in the Fayyum region with the phenomena of renovation of the nature, it is stated: "il tuo corpo giace nella Terra del Lago, o sovrano, vita, forza, salute [...] esce da te la vegetazione dell'inondazione e le giovani piante dai prati del dio".

33 Zecchi (2006: 121) states that for the Late Period: "in the Fayyum, Osiris' identity is split into two forms according to the roles and events in the god's life. One is a sovereign who is born to a new life and who secures, through a descendant, the continuity of his royal power (Wsjr jty hry-jb $t 3-s$ s), the other is a king, who after his death, rules in the netherworld (Wsjr hnty jmntt hry-jb $t 3-\breve{s}$ )". Widmer, 2010: 89 , also stresses this dichotomy. 


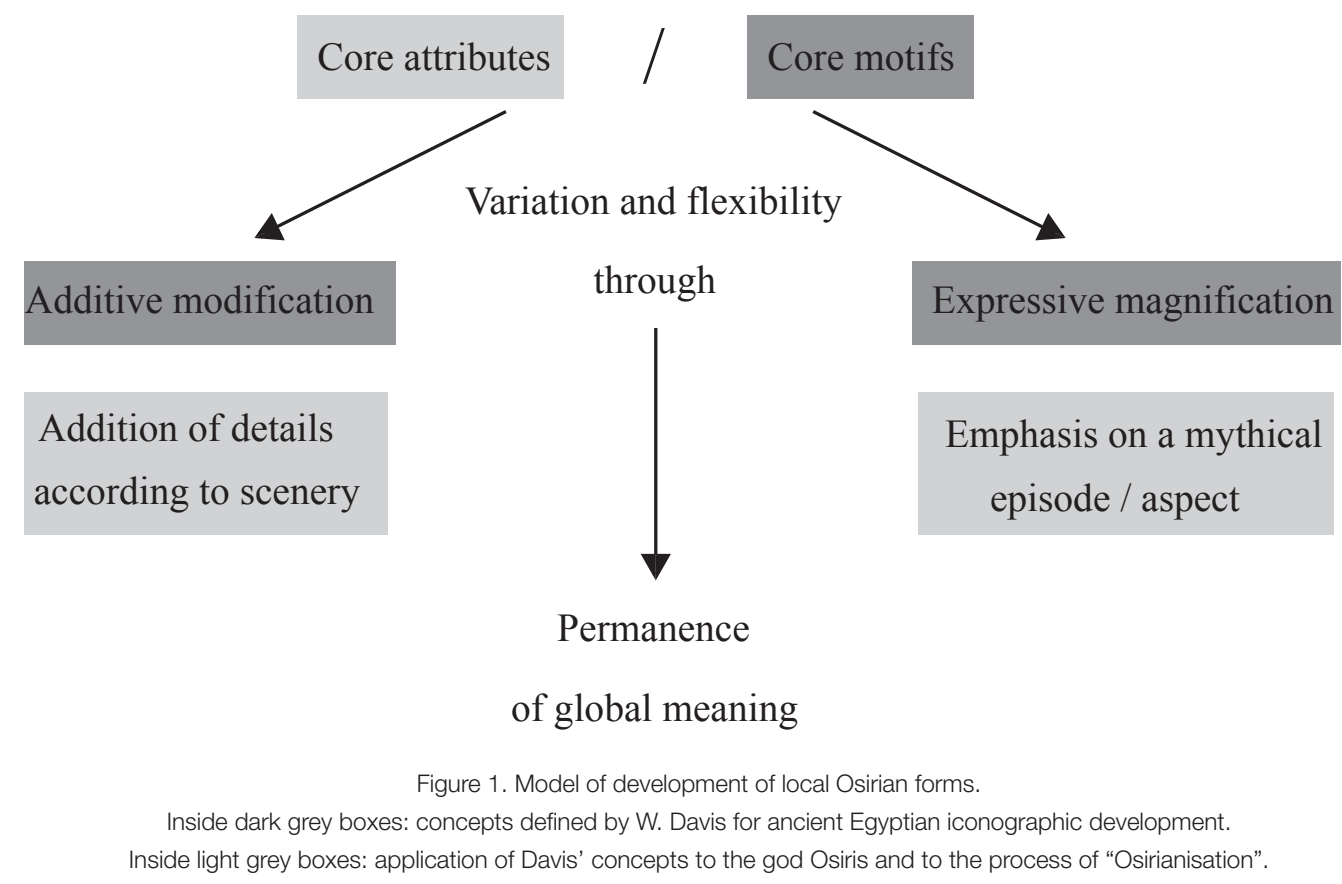

From my point of view, these creative reinterpretations display four characteristics. Firstly, they did not represent major breaks in the core features of the divine figure, but should be understood more as subtle semantic shifts and changes of emphasis. Secondly, these subtleties and prominences served to integrate the specific or local within the general ${ }^{34}$. The integration was fully accomplished when the local manifestation of Osiris reached a supraregional importance and was turned into an element of the shared traditions. Thirdly, and connected to the previous two points, the aspects and episodes magnified and made into the focal point in the development of the new local form were not chosen at random. On the contrary, they were rooted in the provincial context, in the ensemble of religious traditions, or the historical and theological developments of a given region, and/or in aspects of the local landscape. Finally, the flexibility of the resulting creations should be highlighted; there was no tendency towards exclusivity in the relationships established between one or several elements of the god and a region, but rather a preferential connection between both.

Other studies devoted to Osirian local forms different to those already mentioned in section 3 also underline the relevance that the background of traditions of an area had in their origin and essence. In this sense, Philippe Collombert 35 indicates that the particularity of the Osirian cult in the

34 Quack (2008) has tackled the issue of the intertwinement of central and regional conceptions in religious productions.

35 Collombert, 1997: 55-61. 
$7^{\text {th }}$ Upper Egyptian nome, developing in the early Third Intermediate Period, lies in being centred upon the rites over Osiris' corpse and the preparation of his resurrection. According to Collombert, several aspects corroborate this situation: priestly functions documented in the area (such as hlm-ntr Wsjr hnty sh-ntr or nšt of Isis and Nephthys), the gathering of all the members of Osiris' mythical cycle around him, and the fact that the description of the god's rebirth resorts to the image of the divine phoenix (with the cult of the bnw being attested from the New Kingdom onwards in this nome $)^{36}$. In the case of the cult of Osiris in Hwt-Sekhem, all these elements point to the priority given to the mythical episode of rebirth (a further example of the expressive magnification) and to the integration of local beliefs.

Another example has been explored by Vincent Razanajao, who links several specific aspects of the Osirian cult in Imet with the substratum of local traditions and with different topographical realities of the area ${ }^{37}$. Thus, the annihilation rite of Osiris' enemies by Min, who leaps on these as Horus saviour of his father, or the Osirian relics kept in Imet (eyebrows) have a respective corre- spondence in the presence of Min in the local pantheon and in the orthography of the toponym of Imet. From the Third Intermediate Period onwards, coinciding with the phase in which important theological revisions concerning the cult of Osiris and his relics took place, the latter was written with the sign of the eyebrows.

The examples that have been presented in section 3, together with those mentioned in the previous paragraphs, show the complex entanglement between general religious trends and local developments $3^{3}$. The aspects emphasised in the new Osirian form can be conveyed through a variety of means which are not always elaborated upon in the available sources or easy to decode, but should be contextually analysed while always bearing in mind the function for which the specific documents were composed. Among these means are included: epithets, litanies of local forms in offerings or lists of divine names, iconography, compositions and contexts in which the god is mentioned -funerary texts, monumental inscriptions, temple scenes, etc., whether in the private or the official domain 39 . One should also pay attention to more subtle means: relationships established between the local form and oth-

36 Collombert, 2012: 343, 358-36o.

37 Razanajao, 2006.

38 The expansion of the cult of other gods can follow similar avenues, interweaving the general and the local. An example derives from the case of Amun of Saka, analysed by Guermeur (2005: 398-400, 543544). Saka was the capital of the $17^{\text {th }}$ Upper Egyptian nome, or a neighbourhood thereof, where the main god was Bata. Amun was worshipped in this place under the form of "Amun, he who foretells victories, the bull, lord of Saka". The epithets attributed to Amun emphasise both the geographical nexus and the integration within the local traditions, given that Bata was conceived of as a bovid. Guermeur also includes in his study general considerations on the local adaptations to which the Theban god Amun was subjected to in the process of the expansion of his cult (2005: 579-584).

39 Concerning epithets, the difference underscored by Budde (2011) between personal and contextual epithets should be borne in mind. An example of a litany with names of Osiris is the spell 142 of the Book of Going Forth by Day. Quack (2000: 74-83) has published another offering litany in a papyrus of the Thirtieth Dynasty or beginning of the Ptolemaic Period and he refers to similar compositions (2000: 
er deities (the divine constellations in question), mythical episodes highlighted in the area, relics kept in the region, objects or qualities handed by the god to the king in temple scenes in response to the cultic acts executed by the latter, priestly titles, and specific rituals ${ }^{4}$.

It is important to remark that the local Osirian manifestations are a complex and ingenious intellectual construction. It is difficult to specify the extent to which the intricacies of these local forms and of the underlying theological speculations were extended beyond the limited literate elite. Meaningfully enough, the degree of expansion of some of these was narrow. In the case of Osiris Hemag, for example, his cult seems to have been limited to a group of individuals with the highest social status and the most refined education, comprising the king, members of the royal family, and high officials ${ }^{41}$.

To conclude, it should be mentioned that the process of "Osirianisation" does not only consist of the local creative reworking described above. It is a far more complex process: it includes a parallel phenomenon, which contributed to the peak of Osiris' cult in the First Millennium BCE and to the increase in the construction of chapels devot- ed to Osiris within the Karnak precinct. This phenomenon comprised the borrowing and adaptation of prestigious Osirian forms of important nuclei such as Abydos, Coptos, or Heliopolis in other centres (such as Thebes), which, simultaneously, constitutes a sign of the complex interactions among the different religious metropolises ${ }^{42}$.

In this sense, comprehensive and ongoing research conducted by Laurent Coulon on the Osirian materials found in Karnak are shedding light on a particularly intricate scene of adoptions and adaptations of Osirian forms in Thebes. According to Coulon, during the Twenty-fifth and Twenty-sixth Dynasties, figures of the god who were conceived as prestigious references and who embodied central features of the Osirian mythical cycle, found a place of cult in the North and North-East parts of the main Theban sanctuary ${ }^{43}$. These are the cases of the Abydene theological creations around the fetish and the Coptite traditions around the rebirth of the god in the Enclosure of Gold ( $h w t n w b)$ ). Both were transferred to Karnak and found expression, for example, in the chapel of Osiris Wennefer, $n b \underline{d} f 3 w$ (lord of provisions), or in the catacombs where figures of the deity were deposited annually during the mysteries en-

77, n. 18). The iconographic characteristics of several Osirian forms are explored by Zecchi, 2006: 122 and Widmer, 2010: 92-93 (for Osiris jty), Zecchi, 1996: 78-79, 81 (for Osiris Hemag), Díaz-Iglesias, 2017, 2017: 130-140 (for Osiris Naref).

40 Essential elements of the Osirian mythical cycle in the regions of Lower Egypt are transmitted in the socalled Delta papyrus (pBrooklyn 47.218.84, published by Meeks, 2006). The issue of Osirian relics has been dealt with by Vernus (1978: 343, 433-438, for the case of Athribis), Beinlich (1984), Coulon (2005a, for the relics in general and, particularly, for the Theban example), and Díaz-Iglesias Llanos (2014: 106116, for the case of the Herakleopolitan area). For the priestly titres spécifiques of each nome in the Late Period (in some cases linked to the Osirian cult), see Klotz, 2014.

41 Zecchi, 1996: 120.

42 Coulon, 2010: 9.

43 Coulon, 2005a: 38 . 
acted in the month of Khoiak. In the first case, the name of the form worshipped in the small ceremonial structure (Osiris $W n-n f r, n b \underline{d} f 3 w$ ) is derived from the Abydene mythical cycle, according to which the head of Osiris was preserved in the chapel of provisions at Abydos and was responsible for the fertilising fluids that brought the rebirth of vegetation ${ }^{44}$. In the latter case, from the Third Intermediate Period onwards, Osiris the Coptite becomes the centre of the Osirian rites celebrated in the North-East of Karnak, where the catacombs are situated. He presides over a chapel built next to the place of burial of the figurines and where the "réservoir/ventre (des humeurs divines)" is mentioned as a relic. Significantly, the same body limb was assigned to Coptos in the Canopic procession of Dendera. More- over, Osiris the Coptite is the centre of the Osirian necropolis ( $s t \mathrm{C} t$ ) and his figure is depicted on the walls of the catacombs in the construction phase of Ptolemy IV45.

On other occasions, aspects or epithets of deities from other regions were absorbed in Thebes in order to construct the singularity of the new Osirian form. This vital religious centre expressed its aspiration to supremacy through the development of the theology of Osiris' birth in Thebes ${ }^{46}$. The epithet $n b$ wn ("Lord of Light") or the idea of wn/wnj-light ("divine light"), which originally formed part of the Heliopolitan traditions, were subsequently integrated in the characterisation of the figure of Osiris who is born in the first epagomenal day in the temple of Opet flooding everything with light ${ }^{47}$. Besides, Theban the-

44 Coulon, 2011. Kucharek (2006) suggest that the arched form of the Abydene processional route also left its mark in the layout of the route connecting various Osirian chapels in Karnak. For the relationship between Thebes and Abydos in the Third Intermediate Period, see Leahy, 1990 and Coulon, 2012. The influence of the Abydene model can be perceived in other localities, for example in the way of designating the processional road where the funerary monuments of Imet were situated as $r w \underline{d}$ (Razanajao, 2006: 228, n. i).

45 The presence of Osiris the Coptite in Karnak has been analysed by Coulon, 2005a: 33-35, 2005b: 329333, 2009: 4, n. (a). Ongoing research in the temple of Osiris the Coptite can be followed in the periodical archaeological reports of François Leclère on the website of the CFEETK (Centre Franco-Égyptien d'Étude des Temples de Karnak), http://www.cfeetk.cnrs.fr/index.php?page=axe-3-theme-4 (last accessed $1 / 10 / 2015$ ). For the necropolis of Osirian figures see, among others: Coulon, 2005b, Leclère, 2010 (with references to earlier literature). The relationship between Coptos and Thebes and the influence of the theological developments of each centre upon the other have been analysed by Gabolde, 2002.

46 Herbin, 2003. The inscriptions on a donation stela found in the Opet temple and published by Coulon and Gabolde (2004) allow the authors to trace the consideration of this sanctuary as the birth place of Osiris back to the Twenty-fifth and Twenty-sixth Dynasties. The decoration of the propylon in the temple of Khonsu during the Ptolemaic Period illustrates this topic (Labrique, 2010). Further references to the birth of Osiris in Thebes/Opet are conveniently assembled by Cauville, 1997: 236-238, 267-268; Coulon, 2009: 4, n. (b), 6-9.

47 See Herbin, 1994: 176-177 and 2003: 106-107, Labrique, 2010: 196, 203 and Coulon, 2016 for the use of wn/wny and other forms of light ( $\check{s} s, \check{s} w)$ in the characterisation of the luminous (and primordial) aspect of Osiris in Thebes and his condition as first-born in Osirian hymns and inscriptions in the Opet temple and in statues of the god found in Karnak. Heliopolis was a fundamental model in numerous centres. In Karnak, the Heliopolitan inspiration seems to be more far-reaching than in other places and is constitutive of the Amun theology from the Middle Kingdom onwards (Gabolde, 1998: 145-156). Another Theban form of Osiris, Osiris of Djeme, who is associated more closely with the episode of burial and with food offerings handed by son-deities, emerges from the association of the god Osiris with a primordial form of Amun in this cult space of the western bank: Traunecker, Saout, and Masson, 1981: II, 115-117, 130-142; Herbin, 1984, 1994: 139-146; Coulon, 2005a: 32-33; Labrique, 2010: 197-198. 
ologians combined the imported forms with the local developments and created a complex web of Osirian cults: they constructed the identity of Osiris who dwells in Karnak by means of the opposition and complementarity of the pair represented by the figures of Osiris who is (re)born in Opet and Osiris the Coptite in his tomb ${ }^{4}$.

\section{Conclusions}

The model expounded here applies ideas developed for the iconographic analysis by W. Davis to the figure of Osiris in the local context. It opens up a new avenue for understanding a complex process which integrates general religious trends and local specificities, which reinterprets or re-elaborates in a creative manner the basic or key concepts that define the god to adapt them to the local framework, and which works more through subtle semantic shifts and changes of emphasis than through radical changes. Shedding light on Osiris from the local perspective offers many insights. It is an opportunity to approach a god who was constantly reconstructed and whose personality was enriched through the absorption of local traditions and features of other divinities ${ }^{49}$. It is also an invitation to trace the roots of the development of his different forms that did not rise out of a theological vacuum. Finally, it is also a window from which to analyse the local history and landscapes, the symbolic and cultural role of particular centres, and the religious practices and ideas of the different regions of ancient Egypt.

\section{Bibliography}

$$
\begin{aligned}
& \text { Allen, J.P. } \\
& 2013 \text { "The Name of Osiris (and Isis)", LingAeg } \\
& \text { 21: 9-14. }
\end{aligned}
$$

Altenmüller, B.

1975 Synkretismus in den Sargtexten. (GOF IV/7). Wiesbaden.

Assmann, J.

1991 The Search for God in Ancient Egypt. London. 2003 Mort et au-delà dans l'Égypte ancienne. Paris.

Backes, B.; Dieleman, J. (eds.)

2015 Liturgical texts for Osiris and the deceased in Late Period and Greco-Roman Egypt. Proceedings of the colloquiums at New York (ISAW), 6 May 2011, and Freudenstadt, 18-21 fuly 2012. (SSR 14). Wiesbaden.

BAines, J.; Frood, E.

2008 "Piedad, cambio y exhibición en el Reino Nuevo", Rihao, Revista del Instituto de Historia Antigua Oriental "Dr. Abraham Rosenvasser" 15: 75-106.

EL-BANNA, E.

1989 "À propos des Aspects Héliopolitains d'Osiris", BIFAO 89: 101-126.

Beinlich, H.

1984 Die "Osirisreliquien". Zum Motiv der Körperzergliederung in der altägyptischen Religion. ( $\ddot{A} A$ 42). Wiesbaden.

48 Coulon, 2009.

49 Marco Zecchi's words conveniently summarise the importance of the study of specific forms of Osiris for the global understanding of this god: "The particular inflections that his identity took on through its dissemination in various localities undoubtedly played an important role in the construction and reconstruction of his character, endowing Osiris with multiple attributes and complex connotations" (2006: 117). 
BiCKel, S.

1994 La cosmogonie égyptienne avant le Nouvel Empire. (OBO 134). Fribourg, Göttingen.

Borrego Gallardo, F.L.

2010 El título aúreo del Rey durante el Reino Antiguo. Estudio textual, semiológico e histórico. Doctoral dissertation, Universidad Autónoma de Madrid.

Budde, D.

2011 "Epithets, Divine", in: J. Dieleman and W. Wendrich (eds.): UCLA, Encyclopedia of Egyptology, Los Angeles (https://escholarship.org/uc/item/9ct397mm, last accessed $15 / 10 / 2015)$.

Cauville, S.

1997 Le temple de Dendara. Les chapelles osiriennes. Commentaire. (BiÉtud 118). Le Caire.

Collombert, P.

1997 "Hout-Sekhem et le Septième Nome de Haute-Égypte II: les stèles Tardives", $R d E$ 48: 15-70, pls. I-VII.

2012 "Hout-Sekhem et le Septième Nome de Haute Égypte III: les cultes de Houtsekhem à la XVIIIe dynastie", in: C. Zivie-Coche and I. Guermeur (eds.): "Parcourir l'Éternité », Hommages à Jean Yoyotte, (Bibliothèque de l'École des Hautes Études. Sciences religieuses 156), Turnhout: I, 337-373.

Coulon, L.

2003 "Un Aspect du culte Osirien à Thèbes à l'Époque Saïte: La chapelle d'Osiris Ounnefer Maître des Aliments", Égypte Afrique et Orient 28: 47-6o.

2005a "Les reliques d'Osiris en Égypte ancienne: données générales et particularismes thébains", in: P. Borgeaud and Y. Volokhine (eds.): Les objets de la mémoire. Pour une approche comparatiste des reliques et de leur culte, Berne: 15-46.

2005b "Traurrituale im Grab des Osiris in Karnak", in: J. Assmann, F. Maciejewski and A. Michaels (eds.): Der Abschied von den Toten. Traurrituale im Kulturvergleich, Göttingen: 326-341.

2009 "Une trinité d'Osiris thébains sur un relief découvert à Karnak", in: Ch. Thiers (ed.):
Documents de Théologies Thébaines Tardives, (CENiM 3), Montpellier: 1-18.

2010 "Le culte osirien au Ier millénaire av. J.-C. Une mise en perspective(s)", in: L. Coulon (ed.): Le culte d'Osiris au Ier millénaire av. 7.-C. Découvertes et travaux récents. (BiÉtud 153), Le Caire: 1-17.

2011 "Les uraei gardiens du fétiche abydénien. Un motif osirien et sa diffusion à l'époque saïte", in: D. Devauchelle (ed.): La XXVIe dynastie, continuités et ruptures. Actes du Colloque international organiséles 26 et 27 novembre 2004 à l'Université Charles-de-Gaulle-Lille 3. Promenade saïte avec Fean Yoyotte, Paris: 85-108.

2012 "Une stèle déposée par un grand chef libyen près de la nécropole d'Osiris à Karnak", in: Chr. Zivie-Coche and I. Guermeur (eds.): "Parcourir l'éternité": Hommages à Jean Yoyotte, (Bibliothèque de l'École des Hautes Études. Sciences religieuses 156), Turnhout: 375-386.

2013 "Osiris chez Hérodote", in: L. Coulon et al. (eds.): Hérodote et l'Égypte. Regards croisés sur le Livre II de l'Enquête d'Hérodote, Lyon: 167-19o.

2016 "Les statues d'Osiris en pierre provenant de la Cachette de Karnak et leur contribution à l'étude des cultes et des formes locales du dieu", in: L. Coulon (ed.): $L a$ Cachette de Karnak. Nouvelles perspectives sur les découvertes de G. Legrain, (BiEtud 153), Le Caire: 505-564.

Coulon, L. (ED.)

2010 Le culte d'Osiris au Ier millénaire av. F.-C. Découvertes et travaux récents. (BiÉtud 153). Le Caire.

Coulon, L.; Gabolde, L.

2004 "Une stèle sur le parvis du Temple d'Opet à Karnak", $R d E$ 55: 1-9, pl. 1-6.

Coulon, L.; Masson, A.

2010 "Osiris Naref à Karnak", in: L. Coulon (ed.): Le culte d'Osiris au Ier millénaire av. f.-C. Découvertes et travaux récents, (BiÉtud 153), Le Caire: 123-154.

Davis, W.

1989 The Canonical Tradition in ancient Egyptian Art. Cambridge. 
Derchain, Ph.

1969 Review of J.G. Griffiths, The Origins of Osiris, $R d E$ 21: 166-170.

Díaz-Iglesias Llanos, L.

2012 "Nareref/Naref: una cualidad de Osiris y un espacio para el dios en la provincia heracleopolitana", in: L.M. De Araujo and J. Das Candeias Sales (eds.): Novos Trabalhos de Egiptologia Ibérica, IV Congreso Ibérico de Egiptología, Lisboa: 375-392.

2014 El ciclo mítico de Heracleópolis Magna. Continuidad y reelaboración a partir de las fuentes funerariasy cultuales. (Aula Egyptiaca-Studia 7). Bellaterra.

2015 "The Role of Osiris in the mythological cycle devised around Heracleopolis Magna", in: P. Kousoulis and N. Lazaridis (eds.): Proceedings of the Tenth International Congress of Egyptologists, University of the Aegean, Rhodes 22-29 May 2008, (OLA 241), Leuven: $1173-1185$.

2017 Naref and Osiris Naref. A Study in Herakleopolitan religious traditions. Berlin.

Diego Espinel, A.

2006 Etnicidady Territorio en el Egipto del Reino Antiguo. (Aula Egyptiaca-Studia 6). Bellaterra.

Favard-Meeks, C.; Meeks D.

2010 "Les corps osiriens : du Papyrus du Delta au temple de Behbeit", in: L. Coulon (ed.): Le culte d'Osiris au Ier millénaire av. F.-C. Découvertes et travaux récents, (BiÉtud 153), Le Caire: 39-48.

Gabolde, L.

1998 Le "grand château d'Amon" de Sésostris 1er à Karnak : la décoration du temple d'Amon-Ré au Moyen Empire. Paris.

GABOlde, M.

2002 "Amon à Coptos", in: Autour de Coptos. Actes du colloque organisé au Musée des BeauxArts de Lyon (17-18 mars 2000), (Topoi Suppl. 3), Lyon: 117-135.

Gabolde, M.; Galliano, G.; Ballet, P.

2000 Coptos: L'Égypte antique aux portes du désert. Paris, Lyon.
Goebs, K.

2002 "A functional approach to Egyptian Myth and Mythemes", FANER 2: 27-59.

Graindorge-Héreil, C.

1994 Le Dieu Sokar à Thebes au Nouvel Empire. (GOF IV/28 1/2). Wiesbaden.

GRIFFHS, J.G.

1980 The origins of Osiris and his cult. Leiden.

Guermeur, I.

2005 Les cultes d'Amon hors de Thèbes. Recherches de géographie religieuse. (Bibliothèque de l'École des Hautes Etudes. Sciences religieuses 123). Turnhout.

Herbin, Fr.R.

1984 "Une liturgie des rites décadaires de Djemê: Papyrus Vienne 3865", RdE 35: 105126.

1994 Le livre de parcourir l'éternité. (OLA 58). Leuven.

2003 "La renaissance d'Osiris au temple d'Opet (P. Vatican Inv. 38608)", RdE 54: 67-129.

HiRsch, E.

2004 Kultpolitik und Tempelbauprogramme der 12. Dynastie: Untersuchungen zu den Göttertempeln im Alten Ägypten. (Achet. Schriften zur Ägyptologie 3). Berlin.

KLOTZ, D.

2014 "Regionally Specific Sacerdotal Titles in Late Period Egypt: Soubassements vs. Private Monuments", in: A. Rickert and B. Ventker (eds.): Altägyptische Enzyklopädien. Die Soubassements in den Tempeln der griechisch-römischen Zeit. Soubassement I, Band 2, (SSR 7), Wiesbaden: 717-792.

Kucharek, A.

2006 "Auf der Suche nach Konstruktionen der Macht. Die Festprozession des Osiris in Karnak", in: J. Maran et al. (ed.): Constructing Power - Architecture, Ideology and Social Practice. Konstruktion der Macht Architektur, Ideologie und soziales Handeln, Hamburg: 1-14, Taf. 18-20.

2010 Altägyptische Totenliturgien 4. Die Klagelieder von Isis und Nephthys in Texten der 
griechisch-römischen Zeit. (Supplemente zu den Schriften der Heidelberger Akademie der Wissenschaften, Philoshophisch-Historische Klasse 22). Heidelberg.

LABRIQUe, Fr.

2010 "Les ancrages locaux d'Osiris selon les inscriptions de propylône de Khonsu à Karnak", in: L. Coulon (ed.): Le culte d'Osiris au Ier millénaire av. F.-C. Découvertes et travaux récents, (BiÉtud 153), Le Caire: 195-215.

LEAHY, A.

1990 "Abydos in the Libyan Period", in: A. Leahy (ed.): Libya and Egypt c. 1300-750 BC, London: 155-200.

LECLÈre, Fr.

2010 "Le quartier de l'Osireion de Karnak. Analyse du contexte topographique", in: L. Coulon (ed.): Le culte d'Osiris au Ier millénaire av. F.-C. Découvertes et travaux récents, (BiÉtud 153), Le Caire: 239-268.

Leitz, C.

2014a Die Gaumonographien in Edfu und ihre Papyrusvarianten. Ein überregionaler Kanon kultischen Wissens im spätzeitlichen Ägypten. Soubassementstudien III. (SSR 9). Wiesbaden.

2014b "Altägyptisch Enzyklopädien", in: A. Rickert and B. Ventker (eds.): Altägyptische Enzyklopädien. Die Soubassements in den Tempeln der griechisch-römischen Zeit. Soubassementstudien I, Band II, (SSR 7), Wiesbaden: 1017-1045.

LuFT, U.

1978 Beiträge zur Historisierung der Götterwelt und der Mythenschreibung. (Studia Aegyptiaca 4). Budapest.

LuiselLi, M.

2014 "Personal Piety in Ancient Egypt", Religion Compass 8/4: 105-116.

Mathieu, B.

2010 "Mais qui est donc Osiris? Ou la politique sous le linceul de la religion (Enquêtes dans les Textes des Pyramides, 3)", ENiM 3: 77-107.
Meeks, D.

2006 Mythes et légendes du Delta d'après le papyrus Brooklyn 47.218.84. (MIFAO 125). Le Caire.

Meurer, G.

2002 Die Feinde des Königs in den Pyramidentexten. (OBO 189). Fribourg, Göttingen.

QUACK, J.F.

2000 "Ein neuer funerärer Text der Spätzeit (pHohenzollern-Sigmaringen II), Z̈̈S 127: 74-87, Taf. X-XVII.

2008 "Lokalressourcen oder Zentraltheologie? Zur relevanz und Situierung geographisch strukturierter Mythologie im Alten Ägypten", Archiv für Religionsgeschichte 10: 5-29.

Razanajao, V.

2006 "La stèle de Gemenefhorbak (Cairo JE 85932). Dieux, fêtes et rites osiriens à Imet", BIFAO 106: 219-244.

Rusch, A.

1957 "Die Theologie des Osiris und die Herakleopoliten", Weiner Zeitschrift für die Kunde des Morgenlandes 54, Festschrift H. Funker zum 80. Geburtstag gewidmet von seinen Freunden und Schülern: 161-167.

Sandman Holmberg, M.

1946 The God Ptah. Lund.

Sмiтh, M.

2008 "Osiris and the deceased", in: J. Dieleman and W. Wendrich (eds.): UCLA, Encyclopedia of Egyptology, Los Angeles. http:// escholarship.org/uc/item/29r70244, last accessed 15/10/2015.

2010 "The Reign of Seth: Egyptian Perspectives from the First Millennium", in: L. Bares, F. Coppens and K. Smoláriková (eds.): Egypt in Transition. Social and Religious Development of Egypt in the First Millennium BCE. Proceedings of an International Conference Prague, September 1-4, 2009, Prague: 396-430.

2014 "Osiris and the Deceased in Ancient Egypt: Perspectives from Four Millennia", Annuaire de l'École pratique des Hautes Études, Ve section 121: 87-102. 
StAdLer, M.A.

2009 Weiser und Wesir: Studien zu Vorkommen, Rolle und Wesen des Gottes Thot im ägyptischen Totenbuch. (ORA 1). Tübingen.

Traunegker, Cl.; Le Saout, F.; Masson, O.

1981 La chapelle d'Achoris à Karnak. (Mémoires du Centre franco-égyptien d'étude des temples de Karnak 2). Paris.

VERnus, P.

1978 Athribis: textes et documents relatifs à la géographie, aux cultes, et à l'histoire d'une ville du delta égyptien à l'époque pharaonique. (BiÉtud 74). Le Caire.

WEGNER, J.W.

1996 The mortuary complex of Senwosret III: a study of Middle Kingdom state activity and the cult of Osiris at Abydos. Doctoral dissertation, University of Pennsylvania.

WIDMER, G.

2010 "La stèle de Paêsis (Louvre E 25983) et quelques formes d'Osiris dans le Fayoum aux époques ptolémaïque et romaine", in: L. Coulon (ed.): Le culte d'Osiris au Ier millénaire av. F.-C. Découvertes et travaux récents, (BiÉtud 153), Le Caire: 63-97.

ZECGHI, M.

1996 A Study of the Egyptian God Osiris Hemag. (Archeologia e storia della civiltá egiziana e del vicino Oriente antico. Materiali e studi 1). Bologna.

2001 Geografia religiosa del Fayyum: dalle origini al IV secolo a.C. (Archeologia e storia della civiltá egiziana e del vicino Oriente antico. Materiali e studi 7 ). Bologna.

2006 "Osiris in the Fayyum", in: S. Pernigotti and M. Zecchi (eds.): Fayyum Studies 2, Bologna: 117-145.

2010 Sobek of Shedet: the crocodile god in the Fayyum in the dynastic period. Todi.
* This paper derives from two lectures given at the University of Basel, within the Ägyptologisches Forschungsseminar, Current Research in Ancient Egyptian Religion (under the title: Shedding light on Osiris from the local perspective, 3/04/2014) and in Cuenca, at the V Iberian Congress of Egyptology (El desarrollo de las formas osirianas locales: un modelo explicativo, 9/03/2015). I am grateful to the organizers of these events (Susanne Bickel and Antonio Pérez Largacha) and to the participants for their comments. 
Trabajos de Egiptología

Papers on Ancient Egypt 


\section{Consejo editorial}

\section{Director}

Miguel Ángel Molinero Polo

Universidad de La Laguna, Tenerife, Islas Canarias

\section{Secretaría de edición}

Lucía Díaz-Iglesias Llanos

Centro Superior de Investigaciones Científicas, Madrid

Alba María Villar Gómez

Universidad Autónoma de Madrid

\section{Colaborador de edición / English editorial assistant}

Kenneth Griffin

Swansea University, Gales, Reino Unido

\section{Consejo de redacción}

Antonio Pérez Largacha

Universidad de Castilla - La Mancha

José Ramón Pérez-Accino Picatoste

Universidad Complutense de Madrid

$M^{a}$ Covadonga Sevilla Cueva

Universidad Autónoma de Madrid

\section{Comité científico}

Josep Cervelló Autuori

Universitat Autònoma de Barcelona

María José López-Grande

Universidad Autónoma de Madrid

Josep Padró i Parcerisa

Universitat de Barcelona

M. ${ }^{a}$ Carmen Pérez Die

Museo Arqueológico Nacional, Madrid

Esther Pons Mellado

Museo Arqueológico Nacional, Madrid

José Miguel Serrano Delgado

Universidad de Sevilla 
Trabajos de Egiptología

Papers on Ancient Egypt

Número 7

2016 


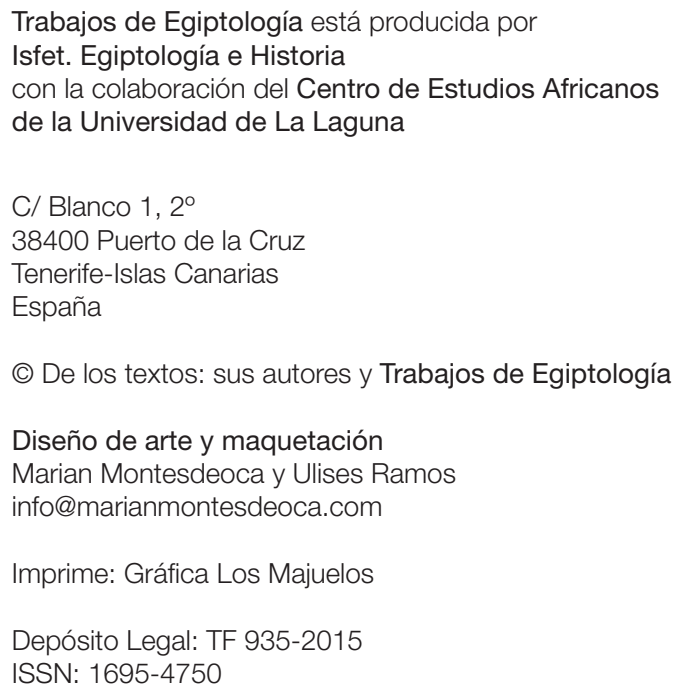




\section{Contents}

$\begin{array}{ll}\text { Prefacio/Foreword } & 7\end{array}$

Chiefs, Kings, and Patrons. Leadership and Social Logics in the Beginnings of Ancient Egypt 9 Marcelo CAMPAGNO

The Development of Local Osirian Forms. An Explanatory Model

Lucía DÍAZ-IGLESIAS LLANOS

Shaushka, the Traveling Goddess

Graciela GESTOSO SINGER

What are we Talking about when we Talk about Memphis?

Maria Helena Trindade LOPES

Stone Vessels of Egyptian Appearance from Ibiza

67

María José LÓPEZ-GRANDE

The Argentine Archaeological Mission at Tell el-Ghaba. A Third Intermediate-Early Saite Period Site on the Ancient Egyptian Eastern Border. Remarks and Main Results

Silvia LUPO

TT 209. Objectives of the proyecto dos cero nueve and the Name of the Tomb Owner Miguel Ángel MOLINERO POLO

The Herakleopolis Magna Project (Ehnasya el Medina). Summary and Results of Work 2000-2015

M. ${ }^{a}$ Carmen PÉREZ DIE

Tombs of the Roman Period in Sector 26 of the High Necropolis Archaeological Site of Oxyrhynchus, El-Bahnasa

Esther PONS MELLADO

The Decoration of the Pronaos of Petosiris' Tomb. Themes, Scenes, Styles and Techniques José das Candeias SALES

The Artist in his Context: New Tendencies on the Research of Ancient Egyptian Art Inmaculada VIVAS SÁINZ 